\title{
Taking on the C-word
}

\author{
Review by Teresa M. Mares* \\ University of Vermont
}

Review of A F oodie's $\mathrm{G}$ uide to $\mathrm{C}$ apitalism: U nderstanding the Political E conomy of W hat W e E at, by Eric Holt-Giménez. (2017). Published by Monthly Review Press. Available as hardcover, paperback, and ebook; 280 pages. Publisher's website: https:/ / monthlyreview.org/ product/ a foodies guide to capitalism/

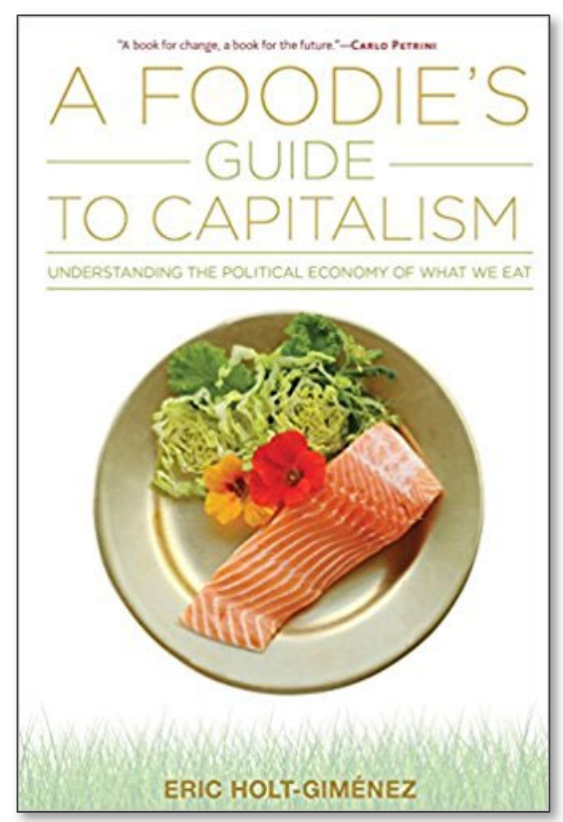

Submitted March 16, 2018 / Published online April 27, 2018

Citation: Mares, M. M. (2018). Taking on the C-word [Book review]. Journal of A griculture, F ood Systems, and Community D evelopment, 8(2), 151-152. https:/ / doi.org/ 10.5304/ jafscd.2018.082.002

Copyright @ 2018 by the Author. Published by the Lyson Center for Civic Agriculture and Food Systems. Open access under CC BY license.

W hat role does love play in challenging the devastating impacts of capitalism on our food system? What role does hope play? For HoltGiménez, the author of A Foodie's $\mathrm{G}$ uide to Capitalism, both love and hope are essential in building a more just and sustainable world, and his newest book is inspired by his long career of allying with

* Dr. Teresa Mares is associate professor of anthropology at the University of Vermont. She is writing a book on border politics and food access issues among Latino/ a dairy workers in Vermont, entitled The 0 ther Border: Sustaining Farmwork ers in the $\mathrm{D}$ airy Industry. She is co-director of Huertas, a food-security project for Latino/ a dairy farmworkers. She is devoted to experiential, transformative modes of teaching and has advised dozens of students who seek to make a difference in the contemporary food system. She can be reached at Teresa.Mares@uvm.edu. those "for whom giving up was not an option" (p. 240). Concluding a treatise on understanding the inner workings and history of capitalism with a call for love and hope might seem trite at first glance. And yet, this is perhaps the best indication of the narrowness and cynicism that often dominate the thinking of those of us who consider ourselves food activists. Another world is indeed possible, and Holt-Giménez gives us the tools we need to better understand the ways that capitalism - and racism - and sexism - and classism - stand in the way of that world. This is the kind of intersectional analysis that we need in the face of climate change, the plundering and privatization of our natural resources, and the ongoing attacks on democracy and progressive politics. A F oodie's $\mathrm{G}$ uide to 
Capitalism allows the reader to understand how these kinds of wicked problems are interrelated with the ways that food is grown, distributed, consumed, and wasted.

Holt-Giménez takes us from his the first chapter, "How O ur Capitalist Food System Came to Be," and guides us through subsequent chapters focusing on the commodification of food, the birth of the private-property system amidst the growth of agriculture, power and privilege in the food system, and finally, the crises and solutions in our food system. The conclusion, entitled "Changing Everything: Food, Capitalism, and the Challenges of our Time," reminds us that it is not only the food system that needs change, but indeed, it is everything.

Holt-G iménez writes primarily for a U.S.based audience, stating that this book "applies a food-systems framework to explain some of the basic workings of capitalism, and uses a basic understanding of capitalism to understand why the food system works as it does" (p. 14). This systems framework allows the author to take a holistic approach that acknowledges the interconnections between the food system and capitalism that food movement activists often overlook as they take on the immediate problems that confront them. As the author notes, this is understandable given the enormity of the problems, but it also "eclipses work to build longer-term political movements that could address the root causes of these problems" (p. 14). Combined with the fact that the political economic structures of capitalism are often taken for granted as immutable, Holt-Giménez endeavors to denaturalize capitalism by outlining the ways that it has been deliberately built by those who stand to benefit from it.
One major strength of this book is its accessibility and readability, a testament to HoltGiménez's clear and coherent writing and narrative tone. I could equally imagine suggesting that my mother read this book in her pursuits to better understand the power of Monsanto and Cargill or assigning it to graduate students in our Ph.D . program in Food Systems who are grappling with social theory. Often overlooked in the back matter, the glossary offers a useful shortcut to the key concepts, institutions, and historical moments that are detailed in the book. The essays written by food activists like Rosalinda $\mathrm{G}$ uillen and $\mathrm{G}$ eorge Naylor also lend a polyvocality that nicely complements Holt-G iménez's own analysis. Moreover, the sidebars that zero in on topics such as "Food Waste at a Glance," "The Pedagogy of the O ppressed," and "Women Farmworkers" outline areas that the reader can explore further with the aid of the author's helpful references.

As an anthropologist, I particularly appreciated the author's historically rooted analysis of the coevolution (or co-devolution) of private property, the commodification of food, and the changing nature of human social structure over time. This is precisely the take on history that I attempt to teach in my classes on food and culture, and I know that my students would find this concise yet detailed analysis exceedingly useful. Knowing this history is key to understanding our contemporary food system and how it shapes and is shaped by our cultural values and priorities. At its core, A F oodie's $\mathrm{G}$ uide to $\mathrm{C}$ apitalism is an expertly written guidebook on how we might revalue food and those who bring it to our table as we work toward a more just and sustainable world. 